\title{
Political Symbolism and Censorship: \\ The Tree Climber and Al-Farafir Revisited
}

\section{Dina Amin*}

The period that followed the Egyptian Revolution of 1952 was euphoric with enthusiasm as the expectations of the population as well as that of the intelligentsia were soaring high. No sooner however, did the optimism escalate that it receded as Gamal Abdel Nasser ${ }^{1}$ who started off as an advocate for freedom and democracy turned into a despot (at least from the point of view of a portion of the population). Attempts at criticism were met with censorship on all fronts. After a number of writers and artists were imprisoned for their political views, some writers opted to stay silent, some conformed and some went around censorship by using symbolism and metaphor.

An art form that suffered tremendously from censorship was theatre and playwriting. While theatre in Egypt could have been debilitated by censorship throughout the 1960s, a decade that suffered greatly from the suppression of speech, it ironically flourished instead, largely due to the pervasive use of symbolism and metaphors by dramatists. How playwrights converted their skepticism about the failure of the revolution to fulfill its promises of democracy into creative art is what I will try to examine herein. Taking Ya Tali 'al-Shagarah (1962; published in English as The Tree Climber, 1966) by Tawfiq al-Hakim and Al-Farafir (Flipflap and His Master, 1964) by Yusuf Idris as projections of political discontent, I will argue that while both use theatre of the absurd as a form, the two texts uphold political symbolism as modus operadi in their covert criticism of the regime. ${ }^{2}$

According to Abner Cohen in "Political Symbolism," the poetics of symbols lie in their ambiguity and multileveled connotations,

It is the very essence and potency of symbols that they are ambiguous, referring to different meanings, and are not given to precise definition. The most dominant symbols are essentially bivocal, being rooted, on the one hand, in the human condition, in what may be called "selfhood," and on

\footnotetext{
* Associate Professor of Drama and Performance Studies in the Department of English Language and Literature, Faculty of Arts, Cairo University.

Cairo Studies in English (2019-Summer): https://cse.journals.ekb.eg/
} 
the other the relations of power. $(1979,87)$

Cohen also expresses that direct political critiques are less interesting than symbolic allusions as they tend to lack depth, and in his opinion, "the less obviously political in form symbols are, the more efficacious politically they prove to be" (87). However, to problematize political symbolism on stage, I must first delve, albeit briefly, into a discussion of freedom of expression and censorship.

In "Censorship and Creative Freedom," Catherine O'Leary maintains that,

While it is clear from recent discussions that censorship is more than topdown repression, the notion of a productive or constitutive censorship incorporating forms of cultural control not covered by the obvious apparatuses of official state regulation is both contentious and difficult to pin down. $(2016,5)$

Despite the fact that sources of prohibitions often oscillate between political, religious or cultural biases in society, the dynamics between artists and censorship are virtually always the same worldwide. Within the realities of Arab and Egyptian theater though, the topic of censorship and freedom is perennial and has been tackled heavily from the mid-1950s (and before) until today. Weighing in onto it as well, it would be valuable to consider Althursser's and Foucault's opinion on the matter of censorship as an opportunity to produce new and different art forms. O'Leary argues that both thinkers, "explored [censorship] as a constitutive or productive force in society" (1). This is in fact a case in point in Arab and Egyptian theater whereby under dictatorships and repressive governments playwrights have continued to produce highly creative dramatic works, that bespeaks the angst of their societies, without articulating blatant criticism towards the powers that be. Margret Litvin asserts that in Egypt,

By the 1960 s ... playwrights and directors began to code their political suggestions in more subtle ways. In performance, actors conveyed political messages by inserting ab-libbed phrases or by directing certain lines or genres to the president's box ... In scripts, allegory replaced, or channeled the concerns of social realism. $(2011,48)$

Litvin also comments on the fact that according to Louis Awad, "Critics halfironically dubbed this technique 'symbolic realism' or 'social symbolism"' (48). While this mode of communication has been a formula for dramatists globally 
to defy censorship whenever their creativity clashed with the various forms of censorship, in the Arab World and Egypt, it is virtually a norm. Muhammad al"Amidi asserts that "Drama, with all its concerns, is essentially a search for the reality that is hidden behind illusions, therefore drama is a search for what is kept unspoken" (112). However "Abd al-Nabi Staif's opinion articulated in "The Question of Freedom," is that:

Arab critics seem to have an ambivalent attitude towards freedom in literature. For while they all insist on the writer's freedom to write in the way dictated by his artistic sensibility, they counterbalance this by a constant reference to his commitment towards his society, nation and humanity, to the necessity or inevitability of orientation in literature and art, or to the social, moral, and political function of literature. $(1995,167)$

Staif thus implicates artists insofar as their use of political symbolism. He maintains that some of their literary productions are auto-dictated by selfcensorship rather than by state oppression. This compromise arises from their knowledge that "Political authority does not only have the means to stop the dissemination of the work of art but also of making its producer pay for his or her opposition to or even criticism of established order" (167). Today, Nora Amin describes freedom on stage as a "forbidden tree" (Amin 2019, 17); and explains the process of speech suppression as dominated by "the power of those who have the loudest voice; those who can terrorize; this explains the narrow margin allowed for literary and artistic expression." Similar to what Litvin and Staif have mentioned, she too insists that "the ghoul of censorship, prohibition and exclusion have moved from the outside to the inside of [the subconscious of] the creative artist, thus the mind obstructs its own creativity and freedom by itself" (20).

In most accounts two suggestions about Egyptian theater arise: that there has been censorship as long as there has been theater, and that dramatists more often than not use allegory and political symbolism to communicate their dissent without any blatant criticism to the repressive powers in order to by pass prohibitions of their work. It is also imperative to note herein that value of drama (unlike other forms of literature) is that plays are presented in front of a live audience. This particularity allows for innuendoes and insinuations that outdo the boundaries of the written word and create a subliminal 'other' level of meaning between performers and spectators. This performative level represents the uniqueness of drama as a genre that cannot be controlled or traced by censors 
for the most part. Likewise, Tawfiq Al-Hakim and Yusuf Idris experimented with political symbolism in order to be a "constitutive or productive force" in society rather than become repressed and silenced artists. After all, Litvin states the following: "Many [Egyptian artists in the 1960s] were eager to play their own historic role, that of mediators between the revolution and society... They sought to mediate in the other direction as well, conveying the people's concerns to those in power" (44-45). Ironically, while using the formalistic and elusive form of symbolism, both dramatists believed that they were fulfilling a social and political commitment to their society by way of challenging censorship.

More specifically, it is necessary to shed some light on the promises of the 1952 Egyptian revolution and its general initial goals before presenting an analysis of the two plays under study herein within the perception of political symbolism. At the outset of the 1952 revolution, the Free Officers, architects of the insurgency, did not have a clear ideology but established themselves first and foremost as a reform movement (Goldschmidt 1988, 89). Later they chose an older figurehead, namely General Muhammad Naguib to be their leader (89). Both Naguib and Khaled Mohieldin (another Free Officer) proclaimed that their movement was ad hoc and did not start as a political one, but a reform one intending to hand power to the military afterwards. This is not what happened ultimately for they "set up a watchdog committee to oversee the government, which was called the Revolutionary Command Council (RCC)" (91).

One of the architects of the 1952 Revolution was Gamal Abdel Nasser, who came to power in 1954 after a period of internal power struggle within the RCC. Ultimately, Nasser won the governing seat and General Naguib became a prisoner of his own home, stripped of all power. Nasser's primary concern apart from developing Egyptian Nationalism was to maintain the environment of democracy inherited from the monarchy (Goldschmidt 1988, 99). This desire did not last long, as he soon changed to one who "did not like to share authority, either with his closest associates or...render power to people less qualified and this, in his opinion, included almost everyone" (Wheelock 52). The truth of the matter is that Nasser toppled all the opposing members of the RCC except for a few like Sadat, Mohieddin and al-Shafe $i$, and for sixteen years exercised sole rulership over Egypt. This naturally aggravated both his friends and enemies, but in the face of criticism Nasser resorted to secret police and censorship to clampdown on opposition. The former resulted in violent atrocities and the latter affected Egypt's cultural scene tremendously; that will be the central issue of this paper.

Nasser's major contribution to modern Egypt is resurrecting the country's national identity, and although he started off fighting for democracy, he changed 
to calling for the rule of one party. Mustafa Amin, in his book Li Kul Maqal Azmah (A Story for Every Article, 1987), discusses Nasser's insistence on the one-party rule and his unrelentless efforts to silence all those who opposed him regarding that matter. He says that Nasser, "insists on the one party, and regards that Egypt needs thirty years at least of one-party rule and one-man and onevision" (126). Amin also mentions the fact that Nasser was at the beginning a fervent advocate for free press and that he defended people's rights to criticize him or anyone else in his government for that matter, however, this attitude changed following the opinion of other members of the RCC, Marshall Amer's for instance, whose opinion on the role of the press - which Nasser became in favour of later on - was that "today the solution for the press in Egypt is for the revolution to arrest all journalists without any exceptions, and to put them all in a military prison, and this way the revolution can settle down, so can the press and so can Egypt" (140).

This confusing and shifting policy caused great disappointment to many Egyptians; and in the face of censorship, writers had to chose between writing or not writing. For those who chose the first, it was a hard task to continue making their writing - in spite of restrictions - worth reading. Therefore, some of them resorted to the use of symbolism and metaphor to express their dismay at the political and social situation in Egypt without being harassed for it by the authorities. Some of these writers excelled at the use of symbolic and metaphoric language in their work that they actually passed the scrutiny of censorship inspectors, and others were not as successful and their works were banned. I will take Al-Hakim and Idris as a case in point of dramatists who managed to produce works that created strong reactions within the literary world, but were not considered transgressive or objectionable by the authorities. I will demonstrate that both used political symbolism in The Tree Climber and Al-Farafir respectively and that their political criticism is layered with symbolism, which came through "as part of the very fabric of the play functioning within, as well as enlarging, its surface meaning" (Zimberdo 1962, 10). I will maintain that it is very possible that what allowed the two plays to fall off the radar of censorship at the time is the fact that both playwrights wrote long prefaces to their plays outlining that their intention for writing them was to introduce the (then) new dramatic form of absurdism and to revive indigenous Egyptian popular performance arts for the sole purpose of reinstating the spirit of nationalism, which the regime upheld steadfastly.

Tawfiq Al-Hakim took the theatre of the absurd as a device by which to express his repressed opinions concerning the regime and its failed promises. 
Martin Esslin defines theatre of the absurd as "that which is devoid of purpose.... Cut off from his (man's) religious, metaphysical, and transcendental roots, man is lost; all his actions become senseless, absurd, useless" (1983, 23). This is analogous to the situation of creative writers under Nasser's regime, for they were trapped and lost amidst censorship and restraints. Many authors felt cut off from the social and political environment of their country and consequently underwent phases of alienation from the regime. Some found in theatre of the absurd a reflection of their own predicament and a convenient release to a few of their frustrations as well as an abstruse medium of expression. The opaqueness inherent in the dramatic style of absurdism was a safe space for writers to express their disenchantment with the regime without articulating it overtly. Al-Hakim found refuge in both the form and content of the theatre of the absurd. His definition of the genre appears in his preface to the play, and he expresses both his and Egypt's need for such theatre: "absurd means expressing reality without realism, the reaching out for the ridiculous or illogical in every expression of art; using abstraction to reach new rhythms and new influences" (Al-Hakim 1962, 24).

Thus, by using abstractions and symbols, which are inherent elements in absurdism, he tried to reach new levels of satire by which to influence the political and social order in Egypt without stirring up authorities against him. While Al-Hakim was already considered a cornerstone on the Egyptian drama and cultural scene, he voiced his criticism of the political status quo carefully, perhaps because he realized that expressing opposition would be enough to place him in prison or ban his work. As a result of his excessive caution, Al-Hakim was often accused of conforming to Nasser's censorship and dictatorship (Farag 1987, 67-69). Those claims drove him to defend himself in a book published during Sadat's rule called The Return of Consciousness; in it he asserts that Nasser's era was one that witnessed stern censorship on the press, performance arts and the written word, therefore it was a period of loss of direction and lack of consciousness (Al-Hakim 1985, 19).

Al-Hakim, thus, found a forum for his political discontent and freedom of expression by way of the symbolism and abstractions, which are implicit within the highly nebulous form of the theatre of the absurd. In fact, The Tree Climber can be construed as a representation of Al-Hakim's inner struggle as the opacity of its metaphors and symbols can only demonstrate the level of oppressive censorship surrounding him at the time. The dense symbolism of the play can, therefore, only be deciphered through a process of dismantling the complexity and layers of the symbols in order to make the connection between the political and social currents in Egypt in the sixties, on the one hand, and the characters 
and plot of the play, on the other.

The Tree Climber is Al-Hakim's first absurdist drama, and it takes its title from an old folk song. The play is written in two acts and revolves around the relationship of Bahhadir and his wife Bahhanna, who disappears one day, and he gets arrested for it. She reappears in the second act so he gets released and they both return to their home together. At home, the husband asks his wife about her disappearance: "Bahhadir: Where were you?" $(1966,161)$. This simple question soon develops into a full-fledged argument that enrages Bahhadir and leads him to kill Bahhanna because she refuses to answer.

In the story there are two other important characters: the old servant and the dervish. Their presence in the play intensifies the symbolic dimension for they represent two important elements within the political realm of that time. The old maid serves the purpose of exposition in the dramatic structure. She becomes an important agent presenting a general picture of the life of the couple in question. She mentions in the interrogation process, which takes place after the disappearance of Bahhanna, that both the husband and wife are harmonious and happy together. She also mentions the fact that Bahhanna was married to another man - now deceased - before Bahhadir, and that she was pregnant with a baby girl that she had to terminate her pregnancy in her fourth month. She also reports that Bahhadir is, more than anything else in the world, attached to an orange tree and a green lizard, living under that tree, in the garden of the couple's house.

The dervish, a symbol of faith and religious authority, is one of the most mysterious dramatic characters in the play, for he is the first to inspire Bahhadir with the concept of an 'ideal' tree, one that produces four fruits a year. Moreover, once convinced of the idea, Bahhadir confesses to the dervish that his dream is to kill his wife and bury her under the tree in order to offer her as the greatest sacrifice and fertilizer to the tree. It is worth mentioning that the dervish had already prophesied earlier on in the play that Bahhadir would kill Bahhanna and present her as fertilizer for the tree. When the prophesy comes true, Bahhadir lets the dervish in on his secret, that he has killed his wife, hoping for his support. Instead of defending his endeavor, the dervish detaches himself from all responsibilities toward the crime, which leaves Bahhadir feeling forsaken by his spiritual leader:

Bahhadir: You knew that I was going to kill her.

Dervish: Knowing is not consenting. (196)

It is obvious that the dervish denies any connection to the crime, which he had 
previously foreseen. Not just that, he advises Bahhadir to bear the responsibility of his actions and points out the importance of burying Bahhanna. The dervish also explains to Bahhadir that he is up against two choices: either admit his crime and bear the consequences or be silent about it and live with a guilty conscience and fear lest his crime is ever discovered in the future. Bahhadir chooses to be silent, and severs his ties with the symbol of faith, the dervish; he continues with his plan and offers Bahhanna's body as fertilizer to his tree so that it may grow bigger and produce more.

After having explored the plot of the play rather briefly, it is necessary to reflect on the Bahhanna and Bahhadir relationship, for it is the material point of the play and virtually all actions are centered another around it. From the course of events we understand that both these characters are rather peculiar, each lives with a certain obsession that dominates their thoughts: Bahhanna is obsessed with the memory of her aborted daughter, which is an emotional journey filled with, pain, memories and idealization of the past. Bahhadir, on the other hand, is obsessed with his orange tree and the green lizard, which he calls, Al-Sheikha Khadra that lives under the tree (and while everybody knows of her, nobody has ever seen her except for him). Bahhanna is focused on her failures in the past, and Bahhadir on the promise of prosperity and materialism of the future - none of them lives for the present moment. When the husband and wife converse, they practically talk at cross-purposes and convey nothing but their respective fixations. They don't even listen to one another; each just picks the last word uttered by the other and builds on it another sentence corresponding to his/her obsession.

Bahhadir: ... what I can't understand is that the wind is very still today, nevertheless, some oranges dropped ... what dropped them?

Bahhanna: (busy with her embroidery) I am the one who dropped her ... she was the first fruit ... and I am the one who dropped her with my own hands.... (54)

Obviously, Bahhadir is talking about his tree and she about her aborted daughter. They continue as such, each in their private world yet believing that there is actually communication between them. Interestingly, the only time they change this conversation pattern and talk to one-another instead of 'at' each other, and actually start talking about the same subject - her disappearance - the situation ends with one killing the other.

On examining the meanings of the play, one realizes that al-Hakim uses symbolism profusely, for each component of the play corresponds to an aspect 
within the political reality of the period. While there are many symbolic elements, it is necessary to start with the tree as it is of the utmost importance for Bahhadir. The tree is in fact the centre of his life; he works for its growth and he is the one who collects its produce. Therefore, he is the owner and ruler of the world of this tree, and his ambitions for it brinks on the impossible if not sheer lunacy. He dreams of it being the 'ideal' tree that produces oranges in winter, apricots in spring, figs in summer and pomegranates in autumn. The tree to Bahhadir can also be compared to Egypt in the eyes of Nasser as he dreamed of an Egypt that would become a model society and 'ideal' country, to be industrial and agricultural on the one hand, and the strongest militarily in the region as well as the leading Arab country in culture and art, on the other, all at the same time. But his dreams led to losses on all fronts like Bahhadir looses everything meaningful in his life. The separation of the dervish and Bahhadir represents the ideology of secularism and materialism that Nasser chose over Islamism, and which turned religious sects against him.

As for Bahhanna, she becomes the symbol of the Egyptian educated and middle class citizens, who endorsed Nasser and hoped that he might compensate Egypt for her past sorrows and tragedies. Her deceased husband represents Egypt's forefathers and patriarchs who historically let the population down. The years of the agony of war and misery of occupation and the loss of Palestine and hope for a better Egypt are symbolized in the aborted embryo of Bahhanna, which represents that Egyptians never realized their dreams. Al-Sheikha Khadra (the green lizard living under the tree) stands for the ideal development and growth of Egypt, green being symbolic of progress, for whom Nasser (Bahhadir) toils, but which only presides in his mind, for no one else has ever seen her (progress), as the servant declares,

The prosecutor: Al Sheikha who?

The maid: The lizard ... he calls that ... I have never seen her ... but he sees her everyday. (50)

The servant represents the working class of Egypt, she totally subscribes to the existence of the green lizard, yet she never saw her herself. Like the people of Egypt who trusted in the presence of prosperity but have not really experienced it, but their belief in Nasser's vision was bigger than their belief in themselves or the reality on the ground around them. Similarly, the servant believes that the presence of the green lizard is unquestionable, simply because her master says so. 
Bahhanna who is mentioned above as being the symbol of intellectuals, forms a symbiotic unit with the maid as two factions of the population. Bahhanna loves her husband and believes in him, as the intellectuals supported Nasser, thinking that he was the upholder of sciences and enforcer of development, until he started encroaching on their freedoms in general. After all,

Most discussions of the question of freedom in literature and art take place within the larger context of the question of freedom in the Arab society, particularly intellectual freedom and the role of thought in general in shaping the modern Arab society or in confronting the challenge facing it at all levels. (Staif 167)

Within the framework of the play this is represented in the character of Bahhanna who stands by her husband until he starts harassing her to tell him where she had been when she disappeared for three days,

Bahhadir: I know how to force you to speak ... I will forcefully make you ... I will make that tongue of yours utter ... I will show you how to speak the answer ... speak now. (183)

But Bahhanna insists on her right to remain silent, and this insistence projects a new dimension in Bahhadir's character that never surfaced before. It is a violent side of him that almost brinks on madness,

Bahhadir: Don't let me press on your neck more that I am already. Speak up ... let your tongue utter the answer. (184)

Her resistance to respond in the face of his violence makes him even more aggressive until he actually kills her. She dies for having held tightly to her beliefs and principles. On the other hand, he kills her as he cannot relinquish total control over her.

This situation parallels the political situation in Egypt at the time, when Nasser's ideology turned from one of securing freedoms to one of trampling over freedoms. Al-Hakim expresses his opinions many years later and after the death of Nasser under the title, 'Absolute ruler', in his book, The Return of Consciousness. He states:

Abdel Nasser became the first man in the country. The country became accustomed to the one-man rule ... The iron curtain was gradually lowered 
between the people and the conduct of the absolute ruler. We loved him without knowing the inner springs of his thoughts or the true motivation for his conduct. Our heart penetrated the curtain to reach him, but the mind remained separated from him. $(1985,19)$

Nasser's isolation from and avoidance of the intelligentsia was effective in that their voices stopped reaching him and their silence became irrelevant to him. Oppressing them is symbolized in the play by Bahhadir's violence against Bahhanna. Nasser's disregard of criticism emerged from a need to silence opposition and the way to do so was through isolating thinkers and writers, who were the first to realize th e absurdity of his aspirations for quick, accelerated and unstudied development. Bahhadir speaks out this desire in a discussion with the dervish,

Bahhadir: To me she [Bahhanna] is meaningless, except when I serve her as a meal for the tree, and the tree grows its glorious growth, and produces its unique fruits. $(1966,199)$

The comparison here is between Bahhadir's dream of the ideal tree, and Nasser's dream of the ideal Egypt, and how those dreams turned into nightmares demolishing growth potentials rather than building them. The analogy is also that both men failed immensely in attaining their dreams. After all, murdering Bahhanna resulted in the death of the lizard, which Bahhadir found at the bottom of the pit that was dug up as burial place for Bahhanna. With her death, the symbol of a prosperous future for Bahhadir was amputated in the same way Egypt's cultural soul, embodied in her intellectuals, were stifled by Nasser's oppressive regime.

Al-Farafir, on the other hand, is a play that questions and deconstructs authority, hierarchy and rank. Like al-Hakim, Idris adopts the absurdist style for his play, but instead of using fusha (standard Arabic), he uses 'ammiyyah (colloquial Egyptian). This added in many ways to the success of the play in the 1960 s, as the layperson could enjoy it just as well as the educated. However, in this case, what was harder to understand was its underlying symbolism, which referred to corruption on all levels of authority. According to Al- 'Amidi, Idris's symbolism speaks to the idea that "the notion of make-believe is born from reality. Illusion is the unattained desire to be real" (Al-"Amidi 2014, 112). While many elements within the play fit with the dictates of theatre of the absurd, in the preface, Idris explains that he uses indigenous Egyptian $\mathrm{Al}_{-} \mathrm{Samir}^{3}$ 
performance art as inspiration (Badawi 1987, 156). He elsewhere further explains that reviving local dramatic forms is necessary in the post-colonial period as it indicates a return to national roots in order to attain independence from western art forms: "We are an autonomous, self-sufficient nation. We have our own songs, music, dance and theater. We thank God that we are living in a period in which we have started to search for our identity and are proud of it and [want to] show it" (Idris 2010, 51).

From this point, Idris's approach was deemed a patriotic endeavor, meant to revive national performance heritage. As a sincere effort to connect present dramatic arts with past ones both Egyptian and Arab nationalism, his project was highly debated (and still is today) within important cultural and artistic conversations. Idris introduced the concept of tamasruh as a state of suspension of the role of spectator as a silent viewer of a performance. While tamasruh can at times also includes aspects of didacticism whereby performers can impart wisdom to spectators, in Al-Farafir, "[i]nstead of tamasruh conveying a socially conservative didacticism, however, it generates an open critique that the community explores together, returning to an adab based in communicative relationality" (Sibley 2019, 46). As the form attracted so much attention, its content became less visible to censors within the context of Egyptian theater, thus escaped their censure.

While exploring the play for its anthropological and historical as well as its structural importance has been at the forefront of previous studies, focusing on its political message (as opposed to its philosophical outlook), which is clearly obscured in the play by the poetics of symbolism, is of great importance within the context of Egyptian drama throughout the different periods. Sibley states that "[i]nstead of the global/local binary, Idris posits the model of greater or lesser diffusion. That diffusion, whether it be of language, art, or theater, is grounded in the political conditions that facilitate or hinder the spread of cultural forms" (46). From this point of view, it can be construed that Idris uses political symbolism and absurdism to challenge traditional dramatic forms in order to generate deeper reflections on the political status quo of his time.

This responds to J.L.Styan's suggestion that "[i]n the theatre an object or a situation can immediately suggest an idea or a feeling that is greater than itself" $(1981,3)$. He continues saying that symbolism came about in Europe for the specific need of moving away from naturalism (4); likewise, it peaks in Egypt every time political freedom of expression is being curbed. After all, "despite Idris's poking fun at the Theatre of the Absurd in more that one place, he has certainly made use of its technique in Al-Farafir" (Badawi 1987, 160). Revisiting those techniques used by dramatists in the post-1952 revolutionary 
Egypt can inevitability shed light on contemporary predispositions in dramatic playwriting in the present time.

Al-Farafir is a play in two acts, it starts with an author behind a podium addressing the audience; he introduces his main character Farfur, who is a combination of a clown and a drifter, described by Sibley in the following terms:

the farfür, a harlequinesque persona whose role is to lampoon figures of authority and engage in bawdy banter with the onlookers. As a figure who both entertains and satirizes, the farfur functions as the gadfly who serves a social function for the community engaged in the performance. His satirical representations are educative, ultimately advocating moral conduct, heightening awareness of social responsibilities, and drawing attention to instances of failure among members of the community. (2019, 47)

When Farfur first enters he is looking for a master, any master, and he finds him asleep among the audience. He summons him to the stage and together they explore the meanings and implications of being a master as opposed to being a servant. Once the master is identified the author gets ready to leave, as he walks away from the podium, we realize that he is wearing the top garments of a tuxedo suit but is only in his boxer shorts underneath. The pattern is established that the author will be called upon whenever there are problems in the plot, and every time he reappears he has grown smaller in size until he practically disappears. As for Farfur and his master, they spend most of the first act discussing the role of a master and servant, and the different occupations that they can possibly perform. During this long exchange the Farfur gets to satirize the entire professional set up in Egypt,

Master: Well, what exactly is my work?

Flipflap: You work as my master ... All right you can be a patriotic man of independent means, in a small way of course.

Master: Um. You don't have anything better?

Flipflap: Oh yes. How about being an intellectual?

Master: Well, what do they do where you come from, intellectuals?

Flipflap: They don't do anything. (Idris 1977, 350-351)

Auto-criticism of the effectiveness of intellectuals and their complacency under Nasser's regime is quite blatant in this exchange, and, as they disparage 
intellectuals, the two characters continue mocking the different occupations from law to taxi driving, and quite explicitly criticizing the corruption on all levels,

Yet far from being a solemn work, the play is full of humour: largely through Farfur, his licensed Fool, the author never tires of ridiculing not only political tyranny and social injustice, but also all forms of hypocrisy and cant, and current fashions in thought and art, from existentialism to the Theatre of the Absurd. (Badawi 1987, 159)

After a very protracted exchange, the Master and Farfur ultimately decide to become grave-diggers but the one who is asked to do all the digging is the Farfur. When the latter realizes that he will be doing all the menial work while the Master will get all the credit, he objects, and a dispute over roles ensues; eventually this disagreement calls for the summoning of the author. When the Author shows up, he tells the Farfur never to ask 'why', which clearly pigeonholes him into the subordinate place. The Farfur realizes that the author has prescribed his subordination and therefore, his destiny cannot change, so he accepts the role. After choosing a profession for themselves, the Master and Farfur decide to find wives. They start looking for partners; the master finds two attractive women to marry and the Farfur gets a masculine-looking one (that can possibly be played by a man). After marriage financial concerns become more pressing, as they don't find anyone to bury. Eventually, they come across a volunteer who is willing to die; the master kills him and orders the Farfur to bury him. This pushes the Farfur over the edge so he decides that he has had enough and leaves.

The second act starts after some time has passed with the two characters running into each other again and deciding to go on doing what they did before, namely digging graves. This time the Farfur rebels and clearly refuses to be marginal, however:

They decide to resume their life together but not on the old basis: first, on an equal footing, both as servants ... and then both as masters ... [but] when all these attempted solutions fail, they resolve to turn back to the Author. This time the author is delivered in the form of a bundle, looking like a newborn baby. (Badawi 1987, 159)

Realizing that his destiny is to forever serve the Master, the play ends with Farfur addressing the audience and complaining to them about disorder, inequality and the impossibility of getting rid of the class system or attaining an egalitarian 
society. However, the play also ends with the impression that the action will restart (the same way it did in Act Two) and will keep repeating. This circular structure is expressed by the last utterance of Farfur,

Flipflap: Good people! Flipflaps! Save your brother! My voice is going. Find us a solution! A solution, someone. A solution, otherwise I'll stay like this. There must be a solution; there must be a way out. Your brother's finished. I'm just acting. (His voice fades) It's you who are going round and round. (Idris 1977, 453)

Compounded with this statement, stage directions indicate that the Farfur keeps twirling around the Master and, "revolving silently in rhythm with the beating of the drum. After a minute the curtain comes down, leaving him still revolving" (454).

The movement clearly indicates a continuing rotating motion that does not end with the closing of the curtain, which renders a circular plot reminiscent of Beckett's Waiting for Godot. The final direct address of the Farfur to the audience represents a wake up call that points to the fact that exploitation and class disparity will continue as symbolized by the actor's continuous revolving physical action around his master. Idris obviously had a very bleak opinion of the present and no high expectations for the future, as the play ends with Farfur calling on the readers/spectators to stop 'repeating' the pattern of complacency. The play certainly bashes authority and pokes fun at people at the top. If one of the themes in Waiting For Godot implies that God is dead, Idris implies that God is there but he is mediocre as symbolized in the character of the author, for he is the creator of the world of the play, but he is incapable of running it efficiently and fairly.

The ever-diminishing size and status of the Author is certainly a direct spoof on intellectuals and artists who have become inconsequential within their country's political and cultural scenes. The character of the author can also be interpreted as the state figurehead (Nasser), who is the top authority of the country. The analogy between Nasser and the Author can be assessed through Farfur's relationship with the second, for he constantly looks up to him for answers, but in vain, as the author is so detached that he can no longer empathize with Farfur's predicament. This is suggestive of Nasser's distancing himself from the people who had elected him, and who believed in his ability to change their status to the better, but their expectations were dashed out when no positive resolutions came forth. Therefore, there is a semblance between Nasser and the 
Author insofar as their disconnectedness with and detachment from their subjects lies. The author becomes harder to call upon as the play unfolds, leaving his characters to sort out their problems alone and to fend for themselves, but when he does answer, it is only if they praised him,

Flipflap: Hey! Author!

Master: Be polite you fool! Don't you know all authors like to be respected and revered. And flattered. Especially flattered.

Flipflap: Your Honor the Author! Your Worship the Author! You, best, finest, biggest, greatest, stoutest author!

Author enters, now in the form of a small boy (or, if preferred a midget) only half as tall as the previous AUTHOR. He still wears short trousers. (Idris 1977, 365)

Idris is obviously playing with the metaphor of an ever-diminishing figurehead, referring to the image of Nasser, which in the opinion of intellectuals kept recoiling. Also, the fact that the author responds only to flattery is more than just a hint about hypocrisy, which had become the means by which to communicate with the new aloof Nasser.

The Farfur represents the farmers and working class of Egypt, who thought that Nasser would free them from the master/servant order in society, but who discovered that getting rid of one master meant being bound to another. The play clearly illustrates that the class structure in Egypt never disappeared as the socialist policies of Nasser promised for "the revolution aim[ed] at creating a socialist society without class distinction", only to reappear under a different disguise (Wheelock 53). For most of the RCC members and many of the early supporters of the revolution emerged later on as the pseudo aristocracy of that period: "The young captains, majors and colonels were creating their own elite, and they were loath to surrender their newly gained privileges" (48). This idea is projected very openly in Idris's play, for he portrays the lower classes in Egypt as trapped in the positions of servitude, that there is no way out for them but to accept their subordinate status. It is indeed an extremely pessimistic view of things for as Roger Allen points out:

It is hardly surprising therefore that Idris's nihilistic comments concerning governmental frameworks in this play were not popular in certain quarters $\ldots$ and one very suitable for the genre of the theatre of the absurd, that was founded to express man's cumbersome existence and his entrapment in life. $(1979,118)$ 
The master, on the other hand, is the epitome of this nihilism as Allen mentions, for if there is no chance for the lower classes to attain a better life and independence, then through the symbolism implicit in the character of the master there is no chance for the country either. The master, who symbolizes the new ruling class created by Nasser, is presented as lethargic, conceited and possessing absolutely no skills or qualification. In effect, the image ties in very well with Wheelock's idea that those who came to power under Nasser attained their positions for absolutely no reason, except that they happen to be affiliates of the president or that they were at the right place at the right time. Just like the figure of the master who happened to be there when the author and the Farfur were in the process of looking for a master.

If Al-Hakim presented Bahhadir, the symbol of Nasser, as caring, naive and idealistic, Idris presented him in the character of the Author as mediocre, uncaring and grotesque. And while the al-Hakim chose not to ascribe blame, for in the implications in the play is that the tragedy was that of Nasser and not the country. His use of symbolism expressed that political miscalculations invariably result in isolation and increased violence. Whereas Idris blatantly ascribes blame, not only to authorities but also to the unaware population, who allowed Nasser to become a dictator. He ends the play with unanswered questions and warnings about (in)equality and how it can never be attained so long as there is complacency. In his last speech the Farfur sends a warning to all Egyptians that they are trapped in their own fear of authority, and with is revolving movement, he illustrates that that fear is perpetual, thus until they free themselves they will never experience real freedom and that the pattern of censorship and oppression will also be long lasting.

\section{Endnotes}

${ }^{1}$ I am using the Egyptian spelling of all names, politicians, characters and titles of plays, rather than standard Arabic.

${ }^{2}$ While I am using M.M. Badawi's translation of Al-Farafir into English, I will be using the Arabic tilte, Al-Farafir, when referring to Yusuf Idris's play instead of the translated title, Flipflap and His Master. I will also refer to the main character in the play by his Egyptian name, Farfur, rather than the translated one, Flipflap. The reason for this choice is that I do not agree with the translation of the word farafir as flipflaps. In my opinion, the translation of "Al-Farafir" is best rendered as 'Underdogs;' translating it as 
flipflaps (which is an obscure noun) is quite an odd choice that does not communicate Idris's intention accurately.

${ }^{3}$ My definition of this kind of performance is as follows: "Al-Samir, in gencral, can bc considered a variety show of sorts for it included singing, dancing, dramatics skits and animal shows" (Amin, 2006).

\section{Works Cited}

Al-'Amidi, Muhannad Ibrahim. 2014. Thuna'iyyat al-Haqiqah wa-al-Wahm fial-Masrah: Ma'a Tadbiqat 'ala Nusus Masrahiyya Turathiyya. United Arab Emirates: al-Haya'a al-'Arabiyya lil-Masrah.

Allen, Roger. 1979. "Egyptian Drama after the Revolution." Edebeyat: A Journal of Comparative and Middle Eastern Literatures 4(1).

Al-Hakim, Tawfiq. 1962. Ya Tali' al-Shagarah. Cairo: Maktabat Al-Adaab.

---. 1985. The Return of Consciousness. Transalted by Bayly Winder. New York and London: New York University Press.

Al-Hakim, Tewfik. 1966. The Tree Climber. Transalted by Denys JohnsonDavies. London: Oxford University Press.

Amin, Dina. 2006. "Egyptian theatre: Reconstructing Performance Spaces." The Arab Studies Journal 14(2), (Fall 2006): 78-100.

Amin, Mustafa. 1987. Li Kul Maqqal 'Azmah. Beirut: Al 'Asr Al-Haddith.

Amin, Nora. 2019. Al-Masrah al-Misri al-Mu asir wa-Huquq al-Insan: fi-alMutalaba bi-al-Haq. United Arab Emirates: al-Hay'a al-'Arabiyya lilMasrah.

Badawi, M.M. 1987. Modern Arabic Drama in Egypt, Cambridge: Cambridge University Press.

Cohen, Abner. 1979. "Political Symbolism." Annual Review of Anthropology 8: 87-113. <http://www.jstor.org/stable/2155615>.

Esslin, Martin. 1983. The Theatre of the Absurd. Third Edition. U.K, U.S.A.: Penguin Books.

Farag, Nabil. 1987. Al-Hakim (1898-1987). Cairo: Al-Hay'a al-'Amma lilKitab.

Goldschmidt Jr., Arthur. 1988. Modern Egypt: The Formation of a Nation-State. Colorado: Westview Press, London, Melbourne: Hutchinson.

Idris, Yusuf. 1977. "Flipflop and His Master." The Drama: Arabic Writing Today. Trans. M.M. Badawi. Ed. Mahmoud Manzalaoui. Cairo: American Research Center in Egypt.

---. 2010. "Nahw Masrah Misri," Al Farafir. Cairo: Nahdat Misr lil-Tiba`a wa- 
al-Nashr.

Litvin, Margaret. 2011. Hamlet's Arab Journey: Shakespeare's Prince and Nasser's Ghost. Princeton and Oxford: Princeton University Press.

O'Leary, Catherine. 2016. "Censorship and Creative Freedom." Global Insights on Theatre Censorship. Ed. Catherine O'Leary, Diego Santos and Michael Thomspon. New York and London: Routledge Taylor\&Francis Group.

Sibley, Emily. 2019. "Redefining Theater: Yusuf Idris's Al-Faräfir and the Work of Cultural Decolonization." Alif: Journal of Comparative Poetics 39: 31-62. <http://www.jstor.org/stable/26596423>.

Șțiif, 'Abd al-Nabī. 1995. "The Question of Freedom in Modern Arabic Literary Criticism." Journal of Arabic Literature 26(1/2): 165-74. $<\mathrm{http}: / /$ www.jstor.org/stable/4183371>.

Styan, J.L.. 1981. Modern Drama in Theory and Practice 2: Symbolism, Surrealism and the Absurd. Cambridge: Cambridge University Press.

Vatikiotis, P.J. ed. 1968. Egypt Since the Revolution. New York, Washington: Frederick A. Praeger.

Weelock, Keith. 1969. Nasser's New Egypt: A Critical Analysis. Foreign Policy Research Institute Series no. 8. New York: Praeger.

Zimberdo, Rose A. 1962. "Symbolism and Naturalism in Edward Albee's The Zoo Story." Twentieth Century Literature 8(1), (April 1962): 10-17. 